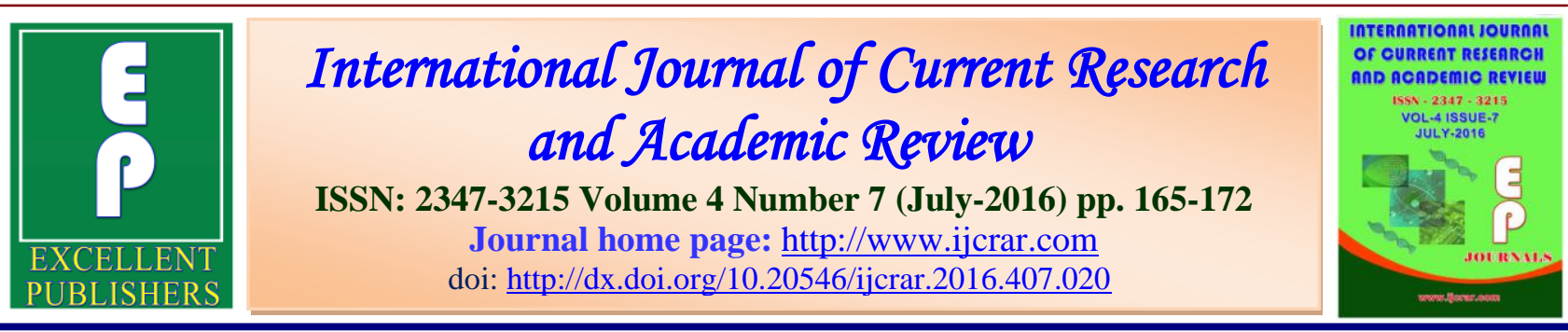

\title{
Pollen Morphology of some Medicinal Plants in Asteraceae form Nigeria
}

\author{
C. Ekeke*, G. C. Obute and N. Ogwu \\ Department of Plant Science and Biotechnology, Faculty of Biological Sciences, University of \\ Port Harcourt, Nigeria
}

*Corresponding author

\begin{tabular}{l|l}
\multirow{2}{*}{ KEYWORDS } & A B S T R A C T \\
\cline { 2 - 3 } $\begin{array}{l}\text { Medicinal Plants, } \\
\text { Asteraceae }\end{array}$ & $\begin{array}{l}\text { The present study investigated the variations and similarities in the pollen } \\
\text { morphology of 13 species of Asteraceae from Nigeria used for different } \\
\text { medicinal purposes. Mature flowers of these plants were cut off, the pollens } \\
\text { dusted on a slide containing a drop of glycerin, observed under microscope } \\
\text { and micro-photographed using Leica WILD MPS 52 microscope camera. } \\
\text { Generally, the pollens are radially symmetrical, isopolar, tricolporate and } \\
\text { spheroidal. The equatorial diameter of the species studied ranged from } \\
17.14 \mu \mathrm{m} \text { to } 55.72 \mu \mathrm{m} \text { while the length of the spines varied generally varied } \\
\text { from } 1.09 \mu \mathrm{m} \text { to } 8.45 \mu \mathrm{m} \text {. The pollen morphology of the species investigated } \\
\text { was found to have diagnostic value and however supports the previous } \\
\text { classification of these plants as distinct species. }\end{array}$
\end{tabular}

\section{Introduction}

The pollen is the structure used in the transport of the male gamete (sperm cells) to the female part of the flower; it is made up of a fine to coarse powder which consists of micro gametophytes (pollen grains), which produce the male gametes of seed plants. Pollen grains are microscopic; usually about 15 to 100 microns and just a pinch of pollen powder contains thousands of grains (Louise, 2008). Pollen is made up of an outer wall called the exine, composed of a very tough unusual substance known as sporopollenin and an inner wall called the intine which is made up of cellulose similar in construction to an ordinary plant cell wall.
Pollen grains come in a wide variety of shapes (most often spherical), sizes and surface markings characteristic to the species. Furrows in the pollen grain called colpi and pores are major criteria for the identification of pollen classes (Dutta, 1964). The differences in these characters can be used in differentiating plants of the same genus or family. It is well known that palynological studies performed by light microscope (LM) and scannini electron microscope (SEM) have great value in plant taxonomy (Skvarla et al., 1977), specifically for the taxonomy of the family Asteraceae (Wodehouse, 1926; Tomsovic, 1997). In 
Nigeria and other countries, members of Asteraceae family are used for several medicinal purposes. These include ethnobotanical, phytochemical, antimicrobial and other medicinal purposes (Teke, et al., 2007; Kamboj and Saluja, 2008; Chono et al., 2009; Abii and Onuoha, 2011; Adebyo, et al., 2010; Arlene, et al., 2013; Toyang and Verpoorte, 2013; Ajiboye, et al., 2014).

In Nigeria some of these plant species are source from the local markets where the sellers may know the proper scientific names of these specimens. Therefore this study is aimed at showing the importance of plant classification based on their natural differences or similarities and therefore is focused on the pollen morphology and structure of some medicinal plants in Asteraceae (Aspilia africana, Tridax procumbens, Tithonia diversifolia, Chromolaena odorata, Ageratum conyzoides, Bidens pilosa, Spilanthes filicaulis, Emilia praetermissa, Vernonia cinerea, Synedrella nodiflora, Eclipta alba, Spilanthes filicaulis and Vernonia amygdalina) and their usefulness in identification and classification of these species.

\section{Materials and Methods}

The plants species were collected within University of Port Harcourt Park and its environs, Rivers State and was taken to the laboratory for microscopic studies. The flowers of the plants were cut off using a scissors, dusted on a slide containing a drop of glycerin to bring out the pollen grains from the anthers and observed under the microscope and micro-photographed using Leica WILD MPS 52 microscope camera. The equatorial diameter of the 20 pollens from each plant species were measured with graticle and the average (mean), standard deviation (STD) and range determine using IBM SPSS Statistics 20.

\section{Results and Discussion}

The external morphology of the medicinal plants from Asteraceae studied is presented in Figure 1 while the results of the pollen grain morphological studies are represented in Table 1 and Figure 2. Among the genera studied, the species have some morphological differences and similarities from each other. For instance, the inflorescence of Aspilia africana, Melanthera scandens and Tithonia diversifolia are fairly similar. However, the morphological differences among these genera have described (Hutchinson and Dalziel, 1954; Akobundu and Agyakwa, 1988).

Generally, the pollens morphology of the species studied are tricolporate, tricolpate, triporate, pantoporate or tri-tetracolprate (Table 1). Among this family, tricolporate pollen type occurred in Ageratum conyzoides (Figure 2a-b) Bidens pilosa (Figure 2e-f) and Vernonia amygdalina (Figure 2w-y) while pantoporate and tritetracolprate types were found in Tithonia diversifolia (Figure 2n-o) and Tridax procumbens (Figure 2p-q) respectively. Tricolpate pollen occurred in Chromolaena odorata (Figure 2g-h), Synedrella nodiflora (Figure 2m) and Eclipta alba (Figure 2t). Based on the external morphology and pollen size, these species are different but they are closely related base on their pollen morphology (Figure 2 and Table 1). Triporate pollen type was the predominant pollen type observed and occurred in Aspilia africana (Figures 2c-d), Emilia praetermissa (Figure 2h), Spilanthes filicaulis (Figures 2i$\mathrm{j}$ ), Vernonia cinerea (Figure 2q) and Melanthera scandens (Figures 2s-t).

Also, the result showed that the mean equatorial diameter of the pollens in the species studied varied from $17.14 \mu \mathrm{m}$ in Bidens pilosa to $55.72 \mu \mathrm{m}$ in Vernonia 
amygdalina (Table 1). The mean of equatorial diameter of the pollens showed that Vernonia amygdalina had the highest Equatorial diameter. This is followed by Tridax procumbens $(39.43 \pm 3.59 \mu \mathrm{m})$, Emilia praetermissa $(32.57 \pm 2.35 \mu \mathrm{m})$, Tithonia diversifolia $(30.86 \pm 3.59 \mu \mathrm{m})$, Vernonia cinerea $(27.47 \pm 2.35 \mu \mathrm{m})$, Aspilia africana $(27.43 \pm 2.35 \mu \mathrm{m})$ and Melanthera scandens $(26.57 \pm 1.92 \mu \mathrm{m})$ while Bidens pilosa had the least mean equatorial diameter of $(19.72 \pm 2.35 \mu \mathrm{m})$. The mean equatorial diameters of the other species are presented in Table 1.

The length of the spines varied from species to species. Generally, it varied from $1.09 \mu \mathrm{m}$ to $8.45 \mu \mathrm{m}$ among the species studied (Table $2)$. The maximum mean length of pollen spine was observed in Melanthera scandens $(7.23 \pm 1.05 \mu \mathrm{m})$ while the minimum length was observed in Vernonia cinerea $(1.41 \pm 0.27 \mu \mathrm{m})$. The mean length of spines in the species include; Ageratum conyzoides $(3.83 \pm 0.71 \mu \mathrm{m})$, Aspilia africana $(7.70 \pm 1.24$ $\mu \mathrm{m})$, Bidens pilosa $(5.54 \pm 0.93 \mu \mathrm{m})$, Chromolaena odorata $(1.96 \pm 0.58 \mu \mathrm{m})$, Emilia praetermissa $(1.77 \pm 0.46 \mu \mathrm{m})$, Spilanthes filicaulis $(5.54 \pm 1.39 \mu \mathrm{m})$, Synedrella nodiflora $(4.13 \pm 0.90 \mu \mathrm{m})$, Tithonia diversifolia $(7.38 \pm 1.02 \mu \mathrm{m})$, Tridax procumbens $(5.32 \pm 0.84 \mu \mathrm{m})$, Eclipta alba $(5.18 \pm 0.88 \mu \mathrm{m})$ and Vernonia amygdalina $(4.87 \pm 0.57 \mu \mathrm{m})$. The variation is this character could be used to delimit the species.

Table.1 Pollen Grain Aperture and Sizes in 13 Plants in the Family Asteraceae Studied

\begin{tabular}{|c|c|c|c|c|}
\hline \multirow[t]{2}{*}{$\mathbf{S} / \mathbf{N}$} & \multirow{2}{*}{ Plants } & \multirow{2}{*}{ Pollen types } & \multicolumn{2}{|c|}{$\begin{array}{c}\text { Equatorial diameter of } \\
\text { Pollen size }(\mu \mathrm{m})\end{array}$} \\
\hline & & & Range & Mean \pm STD \\
\hline 1 & Ageratum conyzoides Linn. & Tricolporate & $17.14-25.72$ & $23.14 \pm 3.83$ \\
\hline 2 & $\begin{array}{l}\text { Aspilia africana (Pers.) C. D. } \\
\text { Adams }\end{array}$ & Triporate & $25.72-30.00$ & $27.43 \pm 2.35$ \\
\hline 3 & Bidens pilosa Linn. & Tricolporate & $17.14-21.43$ & $19.72 \pm 2.35$ \\
\hline 4 & $\begin{array}{l}\text { Chromolaena odorata (Linn.) } \\
\text { R. M. King \& Robinson }\end{array}$ & Tricolpate & $21.43-30.00$ & $25.72 \pm 3.03$ \\
\hline 5 & $\begin{array}{l}\text { Emilia praetermissa Milne- } \\
\text { Redhead }\end{array}$ & Triporate & $30.00-34.29$ & $32.57 \pm 2.35$ \\
\hline 6 & $\begin{array}{l}\text { Spilanthes filicaulis (Schum \& } \\
\text { Thonn) C. D. Adams }\end{array}$ & Triporate & $21.43-30.00$ & $25.72 \pm 4.29$ \\
\hline 7 & Synedrella nodiflora Gaertn. & Tricolpate & $21.43-25.72$ & $22.29 \pm 1.92$ \\
\hline 8 & $\begin{array}{l}\text { Tithonia diversifolia (Hemsl.) } \\
\text { A. Gray }\end{array}$ & Pantoporate & $25.72-34.29$ & $30.86 \pm 3.59$ \\
\hline 9 & Tridax procumbens Linn. & $\begin{array}{l}\text { Tri- } \\
\text { tetracolporate }\end{array}$ & $34.29-42.86$ & $39.43 \pm 3.59$ \\
\hline 10 & Vernonia cinerea (Linn.) Less. & Triporate & $25.72-30.00$ & $27.47 \pm 2.35$ \\
\hline 11 & $\begin{array}{l}\text { Melanthera scandens } \\
\text { (Schumach. \& Thonn) Roberty }\end{array}$ & Triporate & $25.72-30.00$ & $26.57 \pm 1.92$ \\
\hline 12 & Eclipta alba (L.) Hassk & Tricolpate & $21.43-25.72$ & $22.29 \pm 1.92$ \\
\hline 13 & Vernonia amygdalina Delile & Tricolporate & $42.85-55.72$ & $49.72 \pm 4.89$ \\
\hline
\end{tabular}




\section{Int.J.Curr.Res.Aca.Rev.2016; 4(7): 165-172}

Figure.1 Picture Showing the External Morphology of the Asteraceae species: (a) Ageratum conyzoides; (b) Aspilia africana; (c) Bidens pilosa; (d) Chromolaena odorata; (e) Emilia praetermissa; (f) Spilanthes filicaulis; (g) Synedrella nodiflora; (h) Tithonia diversifolia; (i) Tridax procumbense; (j) Vernonia cinerea; (k) Melanthera scandens, (1) Eclipta alba and (m) Vernonia amygdalina
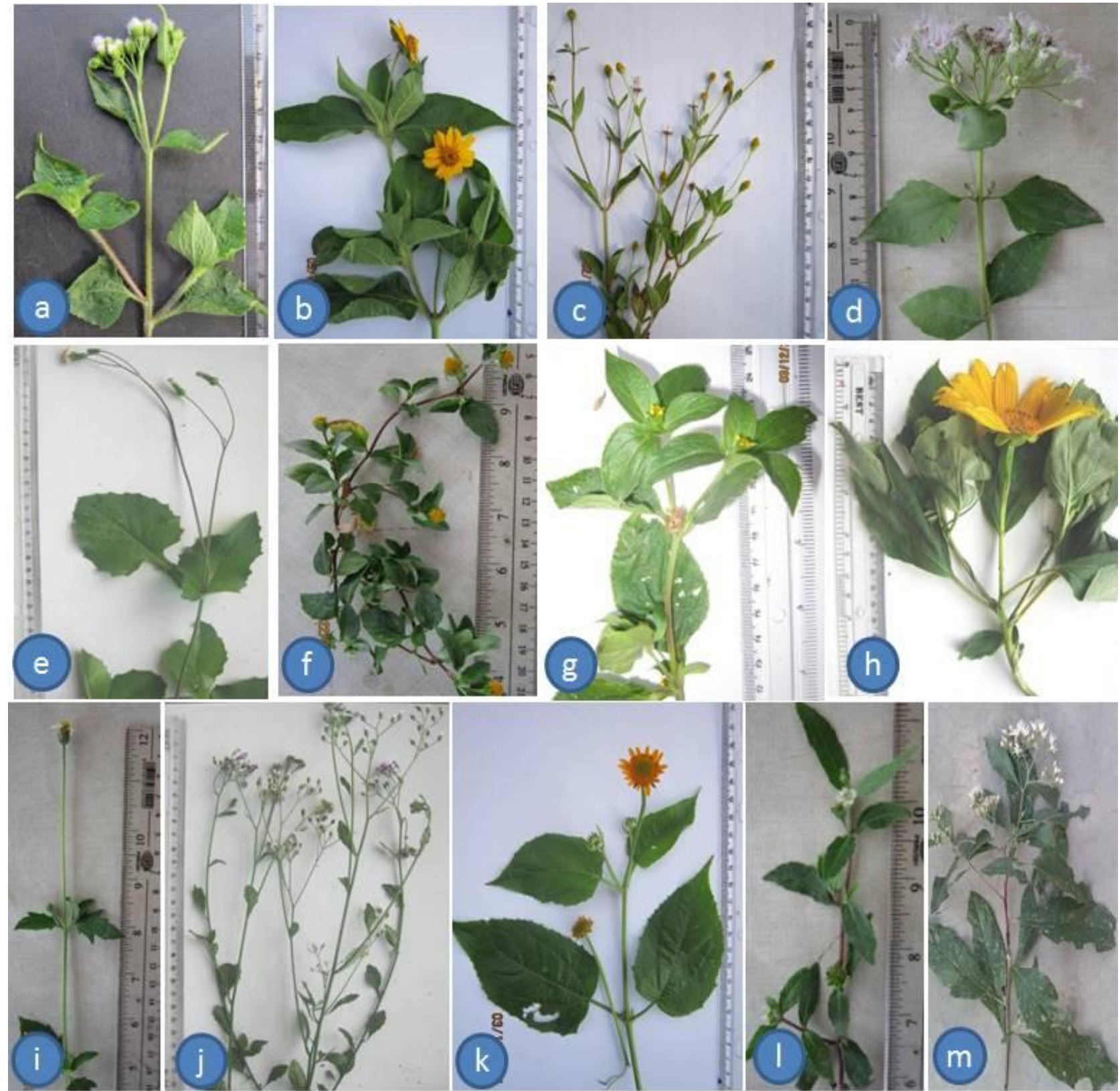


\section{Int.J.Curr.Res.Aca.Rev.2016; 4(7): 165-172}

Figure.2 Picture Showing the Pollen Morphology of the Asteraceae Species: (a-b) Ageratum conyzoides; (c-d) Aspilia africana; (e-f) Bidens pilosa; (g-h) Chromolaena odorata; (i-j) Emilia praetermissa; (k-1) Spilanthes filicaulis; (m) Synedrella nodiflora; (n-o) Tithonia diversifolia; (pq) Tridax procumbense; (r-s) Vernonia cinerea; (t) Eclipta alba; (u-v) Melanthera scandens; (wy) Vernonia amygdalina and scale bar $=15 \mu \mathrm{m}$

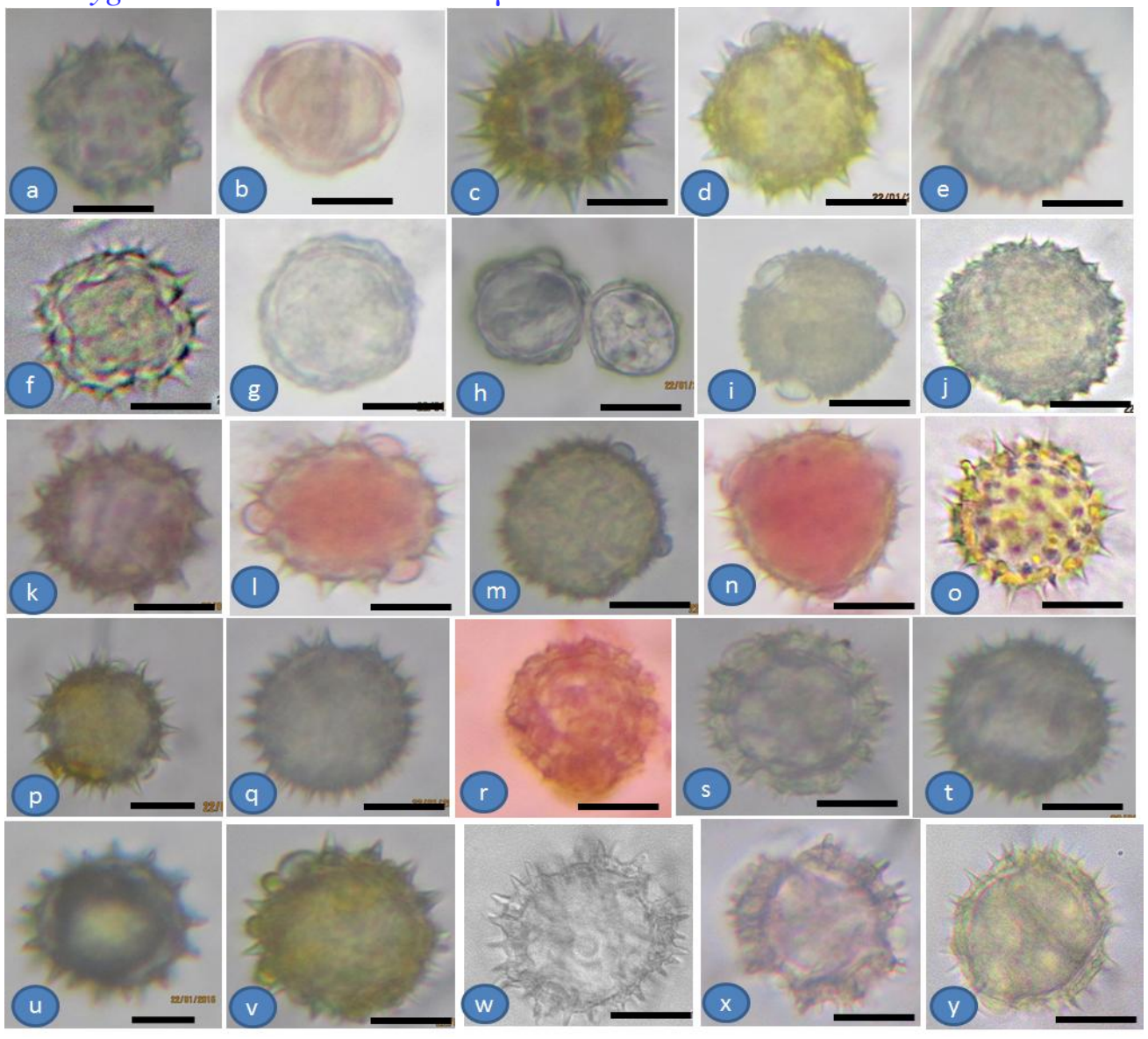

Table .2 Length of Pollen Spines Among the Species Studied

\begin{tabular}{clcc}
\hline S/N & Species Name & Range $(\boldsymbol{\mu m})$ & Mean \pm STD $(\boldsymbol{\mu m})$ \\
\hline 1 & Ageratum conyzoides & $2.86-4.77$ & $3.83 \pm 0.71$ \\
2 & Aspilia africana & $5.45-9.14$ & $7.70 \pm 1.24$ \\
3 & Bidens pilosa & $4.09-6.82$ & $5.54 \pm 0.93$ \\
4 & Chromolaena odorata & $1.36-2.73$ & $1.96 \pm 0.58$ \\
5 & Emilia praetermissa & $1.36-2.73$ & $1.77 \pm 0.46$ \\
6 & Spilanthes filicaulis & $4.09-8.18$ & $5.54 \pm 1.39$ \\
7 & Synedrella nodiflora & $2.73-5.45$ & $4.13 \pm 0.90$ \\
8 & Tithonia diversifolia & $5.45-8.78$ & $7.38 \pm 1.02$ \\
9 & Tridax procumbens & $4.09-6.82$ & $5.32 \pm 0.84$ \\
10 & Vernonia cinerea & $1.09-1.91$ & $1.41 \pm 0.27$ \\
11 & Melanthera scandens & $5.45-8.45$ & $7.23 \pm 1.05$ \\
12 & Eclipta alba & $3.82-6.55$ & $5.18 \pm 0.88$ \\
13 & Vernonia amygdalina & $4.09-5.45$ & $4.87 \pm 0.57$ \\
\hline
\end{tabular}


This present study has revealed the variations and similarities in the pollen morphology of some Asteraceae family in Nigeria. Generally, in Asteraceae, the pollens are radially symmetrical, isopolar, tricolporate and spheroidal. The exine ornamentation is echinate-perforate (ElGhazaly and Anderberg, 1995). The pollens of the species investigated in this study are tricolporate, tricolpate, triporate, pantoporate or tri-tetracolprate which is typical of the family studied. This is in line with the works of Ozmen, et al., 2009, Adekanmbi, 2009, Mbagwu, et al., 2008, Elaheh, et al., 2013. Also, the equatorial diameter of the species studied ranged from $17.14 \mu \mathrm{m}$ to $55.72 \mu \mathrm{m}$.

This range has been recorded in species of the family (Elaheh, et al., 2013, 34.69 to $49.03 \mu \mathrm{m})$ among Centaurea L. (Asteraceae) in Iran, Jafari and Ghanbarian, 2007 (13.9 to $46.0 \mu \mathrm{m}$ ) and Ozmen, et al., 2009 (23.32 to $30.44 \mu \mathrm{m})$. This confirms that the species investigated are members of Asteraceae. Furthermore, the length of the spines varied generally varied from $1.09 \mu \mathrm{m}$ to $8.45 \mu \mathrm{m}$.

Previous studies in the family showed that this result conforms to the values observed among the species of this family however, it was slightly higher. In a similar study involving 13 taxa of Scorzonera L. (Asteraceae) from Turkey, it was observed that the pollen spine length among this taxa varied from 1.3 to $4.63 \mu \mathrm{m}$ (Terkmen, et al., 2010), in Tanacetum L. (Asteraceae) 2.62$3.38 \mu \mathrm{m}$ (Ozmen, et al., 2009).

The morphology of the pollens of the species investigated was found to have diagnostic value and however supports the previous classification of the species by Hutchinson and Dalziel, 1954. It also supports the importance of length of pollen spines as systematic tool in plant taxonomy.

\section{References}

Abii, T. A. and Onuoha, E. N. (2011). The Chemical Constituents of the Leaf of Aspilia africana as a Scientific Backing to its Tradomedical Potentials Agricultural Journal, 6(1): 28-30; $\quad$ DOI: 10.3923/aj.2011.28.30

Adebyo, H., Tan, N. H., Akindahunsi, A. A., Zeng, G. Z. and Zhang, Y. M. (2010). Anticancer and antiradical scavenging activity of Ageratum conyzoides L. (Asteraceae) Pharmacogn Mag. 6(21): 62-66. Doi:10.4103/0973-1296.59968.

Adekanmbi, O.H. (2009). Pollen Grains of Asteraceae and Analogous Echinate Grains. International Journal of Botany, 5: 295-300. doi: 10.3923/ijb.2009.295.300

Ajiboye, A. A., Fadimu O. Y., Ajiboye, M. D., Agboola, D. A., Adelaja, A. B. and Bem, A. A. (2014). Phytochemical and Nutritional Constituents of Some Common Vegetables in South-West, Nigeria. Global Journal of Science Frontier Research: C Biological Science, 1: 4-3

Akobundu I. O. and Agyakwa C. W. (1988). A Handbook of West Africa Weeds. $2^{\text {nd }}$ ed. African Book Builders Ltd., Ibadan, Nigeria.

Anjum P. (1997). Contributions of the Pollen Morphology of the Family Compositae. Department of Botany, University of Karachi. Karachi Pakistan.

Arlene P. B., Irene M. V. and Wen-Chin Y. (2013). Bidens pilosa L. (Asteraceae): Botanical Properties, Traditional Uses, Phytochemistry, and Pharmacology. Evidence-Based Complementary and Alternative 
Int.J.Curr.Res.Aca.Rev.2016; 4(7): 165-172

Medicine, $51 \quad$ pages.

Doi.org/10.1155/2013/340215

Blackmore S. (1986). The identification and taxonomic significance of lophate pollen in the Compositae. Canadian Journal of Botany, 64: 3101-3112.

Briggs D., John B. and Newton B. (2000). Scanning Electron Microscopy and $X$-ray Analysis. North Ampton, MA: Smith College

Chono, A. , Onegi, B., Anyama, N. G, Jenett-Siems, K. and. Malele, R.R.S. (2009). East and Clinical and Parasitological Effects of Aspilia africana (Pers.) C.D. Adams in Fifteen Patients with Uncomplicated Malaria. Central African Journal of Pharmaceutical Sciences, 12: 37-41

Dutta A. C. (1964). Botany for Degree Students. Revised Edition by Dutta, T. C. Head of the Department of Botany. St. Anthony's College Shillong. ISBN-13:978-0-19563748-9, ISBN-10:0-19-563748-8.

Elaheh S. B. S., Farideh A., Hosein R. and Masoud S. (2013). Pollen morphology of Centaurea L. (Asteraceae) in Iran. Acta Botanica Brasilica 27(4): 669-679.

El-Ghazaly G, Anderberg A. A (1995). Pollen morphology of Plirrgrinloii and Aliellri (Asteraceae, Gnaphalieae) and its taxonomical implication. Grana 31: 89-99.

Hutchinson J. Dalziel J. M. and Keay R.W. J. (1954). Flora of West Tropical Africa; Vol. I Part I. Crown Agents for Oversea Governments and Administrations, London.

Ivelisse S. R. (1991). Correlations Between the Structure and Function of Pollen Grains of Four Species of Angiosperms. Scanning Electron Microscopy and X-ray Analysis. Smith College GEO 235j.
Jafari E. and Ghanbarian G. H. (2007). Pollen Morphology Studies on Selected Taxa of Asteraceae. Journal of Plant Sciences, 2(2): 195-201.

Kamboj A. and Saluja A. K. (2008). Ageratum conyzoides L.: A review on its phytochemical and pharmacological profile. Int. J. Green Pharm. 2:59-68.

Louise R. (2008). Pollen Monitoring. The National Pollen and Aerobiology Research Unit, Health, Sciencee, Environment and Forensics. University of Worcester, Henwick Grove, Worcest.

Mbagwu F. N., Chime E. G. and Unamba C. I. N. (2007). Palynological Studies on Five Species of Asteraceae. Department of Plant Science and Biotechnology, Imo State University, Owerri, Imo State. Nigeria.

Ozmen E., Kizilpinar I., Ozudogru B., Dogan C. and Erik S. (2009). Pollen Morphology of Some Taxa of Aromatic Genus Tanacetum L. (Asteraceae). FABAD J. Pharm. Sci., 34, 1-11.

Skvarla J. J, Patel V. C. and Tomb A. S. (1977). Pollen morphology in the Compositae and in related families. In: Heywood VH, Harborne JB \& Turner HI (eds.) Biology and Chemistry of the Compositae. London: Academic Press.

Sukhonthip B. and Pranom C. (2008). Pollen Morphology of the Tribe Vernonieae (Compositae) in Thailand. The Natural History Journal of Chulalongkorn University, 8(1): 4555.

Teke, G. N., Kuiate, J. R., Ngouateu, O. B. and Gatsing, D. (2007). Antidiarrhoeal and antimicrobial activities of Emilia coccinea (Sims) G. Don extracts. J. Ethnopharmacol. 112(2): 278-83. 
Tomsovic P. (1997). Some palynological observations on the genus Echinops (Asteraceae) and their taxonomic implications. Preslia Praha 69: 3133.

Toyang, N. J. and Verpoorte, R. (2013). A review of the medicinal potentials of plants of the genus Vernonia (Asteraceae). J. Ethnopharmacol. 146(3): 681-723. doi: 10.1016/j.jep.2013.01.040.
Turkmen Z., Makbul S., Coşkuncelebi K. and Beyazoğlu O. (2010). Palynological Observations on the genus Scorzonera L. (Asteraceae) from north-east Anatolia (Turkey). Turk. J. Bot. 34: 495-512.

Wodehouse R. P. (1926). Pollen grain morphology in the classification of the Anthemideae. Bull Torrey Bot Club., 53: 479-485.

\section{How to cite this article:}

Ekeke, C., G. C. Obute and Ogwu, N. 2016. Pollen Morphology of some Medicinal Plants in Asteraceae form Nigeria. Int.J.Curr.Res.Aca.Rev.4(7): 165-172.

doi: http://dx.doi.org/10.20546/ijcrar.2016.407.020 